PRODUCTION

ENGINEERING ARCHIVES
2015, No 4, pp 2-5

ISSN 2353-5156 (print version)

ISSN 2353-7779 (online version)

Article history: $\quad$ Received: 16.11 .2015

\title{
Managerial traits in different companies
}

\author{
Manuela Ingaldi ${ }^{1}$ \\ ${ }^{1}$ Institute of Production Engineering, Faculty of Management, Czestochowa University of Technology, Armii Krajowej 19B, 42-201 \\ Czestochowa, Poland, +48 343250 399, e-mail: manuela@gazeta.pl
}

\begin{abstract}
This chapter focuses on identification of managerial traits (defined in 4E+P principles) of the managers in a bakery and confectionery as well as in administration of steelworks. Existence of elements which prove two styles of management used by the managers was observed.
\end{abstract}

Key words: managerial traits, $4 \mathrm{E}+1 \mathrm{P}$ principles, management styles, $\mathrm{BOST}$ investigations

\section{Presentation of 4E+P Principles - Methodology}

The success of the company depends on several factors. Management styles belong to these factors. Management styles are characteristic ways of making decisions and relating to subordinates They require proper management of emotions, setting goals, motivation and assertiveness. They strongly influence manager behaviour. These styles largely depend on a manager's character features (KRYNKE M., MIELCZAREK K. 2013; SZKLARZYK P. 2014; SYGUT P. 2014; KLIMECKA-TATAR D. 2014).

In the study by (FOLTYN H. 2009), a chapter Managers' Behaviour and Education starts from the question presented in two versions: what do managers actually do or what should they do? In the present chapter, another question was repeated as in (WELCH J. WELCH S. 2005): What are the managers made of? During recruitment of managers, the following managerial traits should be considered:

- Is full of enthusiasm all day long (1E).

- Is able to encourage others to take actions (2E).
- Makes decisions fast (3E).

- Knows how to implement decisions (4E).

- Cares for the success by co-workers (1P).

The abovementioned traits are referred to as 4E $+1 \mathrm{P}$ principles (BORKOWSKI S., BLAŠKOVÁ M., HITKA M. 2009) and were proved suitable for assessment of motivation traits among supervisors or home room teachers. The investigations focused on execution of the instruction: please answer YES or NO, putting ' + ' mark for each principle. The results were compared in the tables where the data comprised the basis for calculation of:

- level of YES or NO answer,

- YES/NO quotient,

- YES-NO difference,

- Acceptance of the number of traits $(0,1,2,3,4,5)$. The investigations encompassed three entities: bakery, confectionary, administration of a department in a steelworks. These objects were randomly selected from the number of ten, all of which contained a number of 15 to 20 respondents. The results presented are a part of the data obtained within BOST investigations (BORKOWSKI S. 2009). 


\section{Characteristics of Managerial Traits of Supervisors in Different Enterpris- es}

\subsection{Identification of Managerial Traits of Bak- ery Owner}

Structure of acceptance of managerial traits in Bakery Owner (Tab. 1) shows that in five traits, defined by $4 \mathrm{E}+1 \mathrm{P}$, the respondents did not mention him being full of enthusiasm all day long (1E) and caring for the success of employees (1P). Graphical comparison of the results (Fig. 1) points to a considerable advantage of NO answers over YES answers for these traits. Quantitative comparison of the obtained data were presented in Table 2 and in Fig. $1 b$.

Table 1. Assessments' structure [\%]. Principles 4E+1P.

\begin{tabular}{|c|c|c|c|c|c|}
\hline \multirow{2}{*}{ Result } & \multicolumn{5}{|c|}{ Denotation of principle } \\
\cline { 2 - 6 } & 1E & 2E & 3E & 4E & 1P \\
\hline YES & 46.7 & 73.3 & 53.3 & 66.7 & 26.7 \\
\hline NO & 53.3 & 26.7 & 46.7 & 33.3 & 73.3 \\
\hline
\end{tabular}

Source: own study

Table 2. Quotient YES/NO. Principles 4E+1P.

\begin{tabular}{|c|c|c|c|c|c|}
\hline \multirow{2}{*}{ Result } & \multicolumn{5}{|c|}{ Denotation of principle } \\
\cline { 2 - 6 } & $\mathbf{1 E}$ & $\mathbf{2 E}$ & $\mathbf{3 E}$ & $\mathbf{4 E}$ & $\mathbf{1 P}$ \\
\hline YES/NO & 0.88 & 2.75 & 1.14 & 2.00 & 0.36 \\
\hline
\end{tabular}

Source: own study

Table 3. Assessments' structure [\%]. Principles 4E+1P.

\begin{tabular}{|c|c|c|c|c|c|}
\hline \multirow{2}{*}{ Result } & \multicolumn{5}{|c|}{ Denotation of principle } \\
\cline { 2 - 6 } & 1E & 2E & 3E & 4E & 1P \\
\hline YES-NO & -6.6 & 46.6 & 6.6 & 33.4 & -46.6 \\
\hline
\end{tabular}

Source: own study

a)

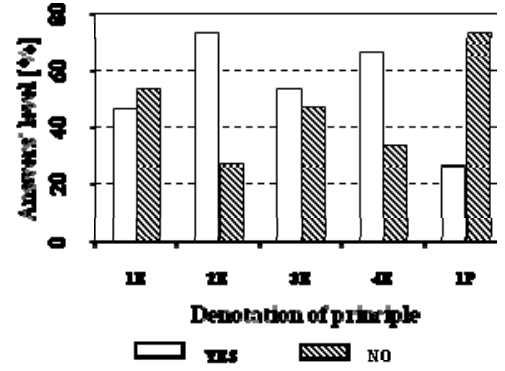

b)

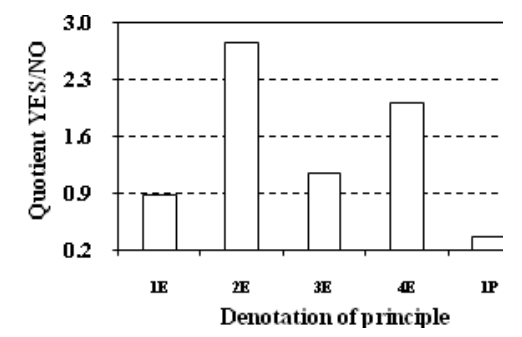

c)

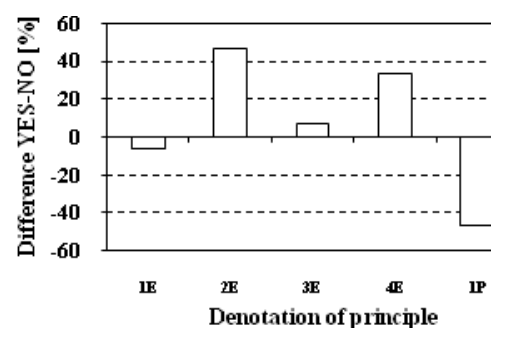

d)

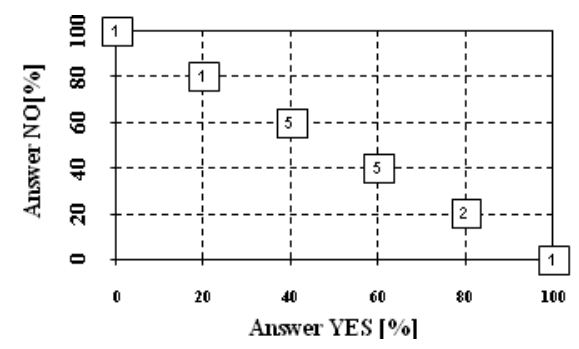

Fig. 1. Supervisor's assessment characteristics based on 4E+ 1P rule: a) answer YES and $\mathrm{NO}$ comparison, b) quotient YES/NO, c) difference YES-NO, d) frequency of the answers in system YES - NO.

Source: own study

As results from them, the level of YES answers, as compared to NO answers, for this trait amounts to 0.36 (1P), 0.88 (1E). The analysed data show that the bakery's owner has an ability to encourage others to take actions (2E), knows how to implement decisions and strives for achievement of goals (4E) which in this case are profits. As can be concluded from Table 3 and Fig. $1 \mathrm{c}$, in terms of the principle of 'makes decisions fast' (3E) the opinions by the employees are divided (difference of YES-NO answers is only 6.6\%). To sum up, one should note that, in employee's opinion, the owner has $50 \%$ of managerial traits contained in $4 \mathrm{E}+1 \mathrm{P}$ principles (Fig. 1d).

\subsection{Acceptance of Managerial Traits of Con- fectionary's Owner}

Which managerial traits contained in $4 \mathrm{E}+\mathrm{P}$ principles were noted in confectionary's owner? A partial answer to the question is presented in Table 4, from which results that he does not care for confectionary's employees success (1P). The level of YES/NO answers (Fig. 2a) shows considerable advantage of YES over NO for: 2E, 3E and 4E. The numeral relationship (YES/NO quotient) is contained in Table 6 and Figure $2 b$. The owner is an energetic person during management of his confectionary, solving problems, distribu- 
tion of tasks and he makes decisions fast $(\mathrm{YES} / \mathrm{NO}=2.75)$. The level of the difference of YESNO (Tab. 6) and Fig. 2c indicate that, in the case of 1E and $4 \mathrm{E}$ principle, the levels of acceptance are similar and do not exceed $20 \%$. Among 15 answers, the acceptance of three and more managerial traits in terms of behaviour and conduct of the confectionary's owner was observed in 9 cases (60\% of the respondents) (Fig. 2d).

Table 4. Assessments' structure [\%]. Principles 4E+1P.

\begin{tabular}{|c|c|c|c|c|c|}
\hline \multirow{2}{*}{ Result } & \multicolumn{5}{|c|}{ Denotation of principle } \\
\cline { 2 - 6 } & $\mathbf{1 E}$ & $\mathbf{2 E}$ & $\mathbf{3 E}$ & $\mathbf{4 E}$ & $\mathbf{1 P}$ \\
\hline YES & 53.3 & 66.7 & 73.3 & 60.0 & 33.3 \\
\hline NO & 46.7 & 33.3 & 26.7 & 40.0 & 66.7 \\
\hline
\end{tabular}

Source: own study

Table 5. Quotient YES/NO. Principles 4E+1P.

\begin{tabular}{|c|c|c|c|c|c|}
\hline \multirow{2}{*}{ Result } & \multicolumn{5}{|c|}{ Denotation of principle } \\
\cline { 2 - 6 } & $\mathbf{1 E}$ & $\mathbf{2 E}$ & $\mathbf{3 E}$ & $\mathbf{4 E}$ & $\mathbf{1 P}$ \\
\hline YES/NO & 1.14 & 2.00 & 2.75 & 1.50 & 0.50 \\
\hline
\end{tabular}

Source: own study

Table 6. Assessments' structure [\%]. Principles 4E+1P.

\begin{tabular}{|c|c|c|c|c|c|}
\hline \multirow{2}{*}{ Result } & \multicolumn{5}{|c|}{ Denotation of principle } \\
\cline { 2 - 6 } & $\mathbf{1 E}$ & $\mathbf{2 E}$ & $\mathbf{3 E}$ & $\mathbf{4 E}$ & $\mathbf{1 P}$ \\
\hline YES-NO & 1.14 & 2.00 & 2.75 & 1.50 & 0.50 \\
\hline
\end{tabular}

Source: own study

a)

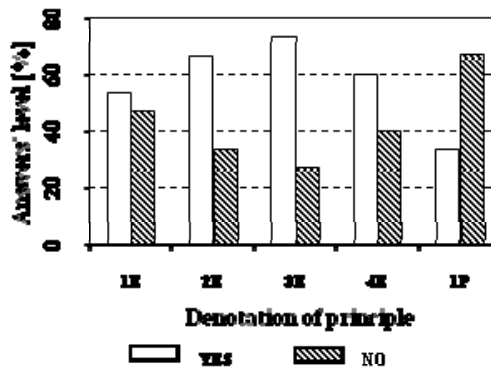

b)

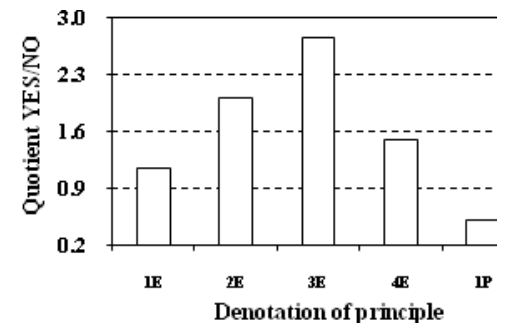

c)

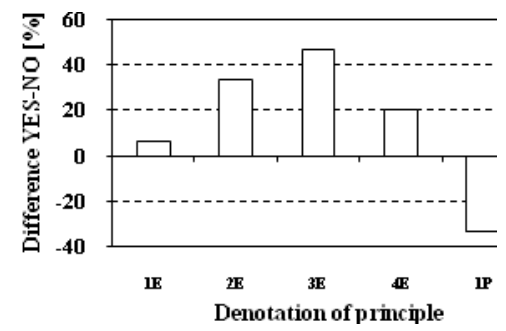

d)

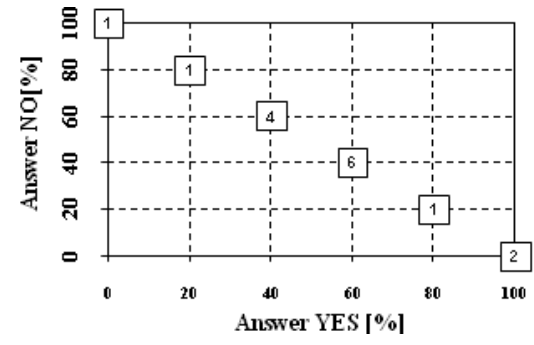

Fig. 2. Supervisor's assessment characteristics based on 4E+ $1 \mathrm{P}$ rule: a) answer YES and NO comparison, b) quotient YES/NO, c) difference YES-NO, d) frequency of the answers in system YES - NO.

Source: own study

\subsection{Management Styles of Industrial Admin- istration}

Administration in industrial enterprises is an interesting investigation object. They have their own supervisor and do not take active part during manufacturing of goods. The influence of this administration on the results of production is directly considerable. The administration of the department in the steelworks commented on managerial traits in their manager in a manner expressed in numbers in Table 7 and Fig. 3. It turns out that, in this case, the manager does not care for the success of the employees working for this division (YES for $1 \mathrm{P}=35 \%$, i.e. below $50 \%$ ). All the remaining traits from $4 \mathrm{E}+1 \mathrm{P}$ obtained an advantage of YES over NO. Quantitative relationships between YES and NO are compared in Tables 8 and 9 and Fig. $3 \mathrm{~b}$ and $3 \mathrm{c}$. The high level of YES/NO quotient $=2.33$ points to the fact that the administration manager in the steelwork department is energetic and makes decisions fast (3E). This might result from the fact that the analysed administration, in many cases, is involved in the realization of the problems which occur during production. Collective comparison of the assessment of the manager (Fig. 3d) indicates that the employees assess their manager as a leader in $55 \%$.

Table 7. Assessments' structure [\%]. Principles 4E+1P.

\begin{tabular}{|c|c|c|c|c|c|}
\hline \multirow{2}{*}{ Result } & \multicolumn{5}{|c|}{ Denotation of principle } \\
\cline { 2 - 6 } & $\mathbf{1 E}$ & $\mathbf{2 E}$ & $\mathbf{3 E}$ & $\mathbf{4 E}$ & $\mathbf{1 P}$ \\
\hline YES & 60.0 & 55.0 & 70.0 & 60.0 & 35.0 \\
\hline NO & 40.0 & 45.0 & 30.0 & 40.0 & 65.5 \\
\hline
\end{tabular}

Source: own study 
Table 8. Quotient YES/NO. Principles 4E+1P.

\begin{tabular}{|c|c|c|c|c|c|}
\hline \multirow{2}{*}{ Result } & \multicolumn{5}{|c|}{ Denotation of principle } \\
\cline { 2 - 6 } & $\mathbf{1 E}$ & $\mathbf{2 E}$ & $\mathbf{3 E}$ & $\mathbf{4 E}$ & $\mathbf{1 P}$ \\
\hline YES/NO & 1.50 & 1.22 & 2.33 & 1.50 & 0.53 \\
\hline
\end{tabular}

Source: own study

Table 9. Assessments' structure [\%]. Principles 4E+1P.

\begin{tabular}{|c|c|c|c|c|c|}
\hline \multirow{2}{*}{ Result } & \multicolumn{5}{|c|}{ Denotation of principle } \\
\cline { 2 - 6 } & $\mathbf{1 E}$ & $\mathbf{2 E}$ & $\mathbf{3 E}$ & $\mathbf{4 E}$ & $\mathbf{1 P}$ \\
\hline YES-NO & 20.0 & 10.0 & 40.0 & 20.0 & -30.5 \\
\hline
\end{tabular}

Source: own study

a)

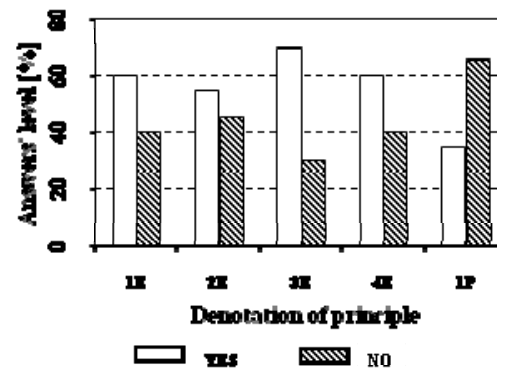

b)

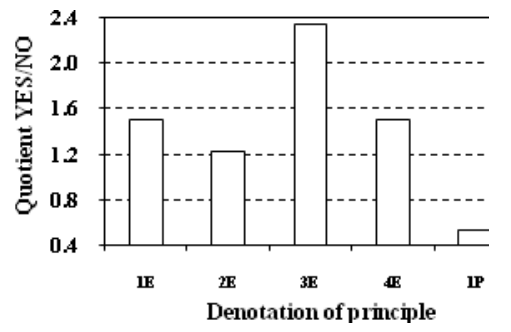

c)

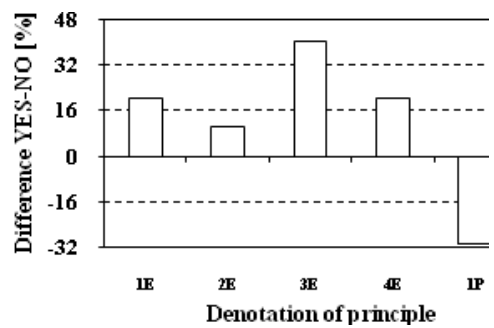

d)

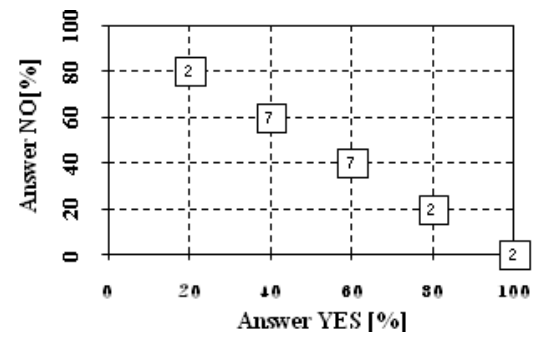

Fig. 3. Supervisor's assessment characteristics based on 4E+ 1P rule: a) answer YES and NO comparison, b) quotient YES/NO, c) difference YES-NO, d) frequency of the answers in system YES - NO.

Source: own study

\section{Summary}

This chapter presents the results of the assessment of managerial traits in the managers in three organizations: bakery, confectionary and administration of the steelworks department. It was observed that, regardless of the nature of the activity in the investigated entities, the managers do not care for the success of their employees (this definition is contained in $4 \mathrm{E}+1 \mathrm{P}$ principles). The managers have ability to encourage others to take actions and they make their decision fast. In two companies, which started their operations in 1990, the autocratic management style prevails. This concerns the bakery and the confectionary, where production problems (striving to survive in the market, reaching maximal profits) take advantage over the owner's interest in human issues. In the investigated entity with a longer history of operation, a balanced approach to production-related and human issues was observed (integrated management styles were found in $95 \%$ of the cases).

\section{Literature}

1. FoŁTYN H. 2009. Praca współczesnych menedżerów, Wydawnictwo Naukowe Wydziału Zarządzania Uniwersytetu Warszawskiego. Warszawa.

2. Welch J. Welch S. 2005. Winning znaczy zwyciężać. Wyd. Studio Emka. Warszawa.

3. BorkowsKi S., BLAŠKOVÁ M., HITKA M. 2009. Toyotarity. Motivation features of managers. BORKOWSKI S., BlaŠKovÁ M., HitKA M. (ed.)Yurii V. Makovetsky. Dnipropetrovsk.

4. BORKOWSKI S. 2009. Zasady zarzadzania TOYOTY w pytaniach. Wyniki badań BOST. Wydawnictwo Menedżerskie PTM. Warszawa.

5. KrynKe M., MielCZAREK K. 2013. An evaluation of realization of the production process in the cement mill. Production Egineering Archives. Vol. 1(1), p.19-21.

6. SZKLARZYK P. 2014. Visual inspection as one of the important elements of the quality control. Production Egineering Archives. Vol. 2(1), p.9-11.

7. SyGuT P. 2014. Process of quality improvement in the company producing building materials. Production Egineering Archives. Vol. 1(2), p.16-18.

8. KLIMECKA-TATAR D. 2014. Importance of development factors in company dealing with cataphoresis coatingmethod. Production Egineering Archives. Vol. 1(2), p.20-22. 